J. Perinat. Med. 14 (1986) 95

\title{
Vacuum extraction: a randomized controlled comparison of the New Generation cup with the original BIRD cup
}

\author{
Frank Carmody ${ }^{1}$, Adrian Grant ${ }^{2}$, and Malinec Somchiwong ${ }^{2}$
}

${ }^{1}$ Department of Obstetrics and Gynecology St. Mary's Hospital, Portsmouth, and ${ }^{2}$ National Perinatal Epidemiology Unit, Radcliffe Infirmary, Oxford, U. K.

\section{Introduction}

Optimal placement of the vacuum cup over the posterior fontanelle in the midline - a flexing, median application - corrects deflexion and asynclitism when traction is applied [2]. The original MALMSTRÖM cup [3] can be difficult to apply in this position if the fetal head is lying in an occipito-lateral or occipito-posterior position. Furthermore, when oblique traction is applied to this cup it tends to become detached.

BIRD [1] made important modifications to the MALMSTRÖM cup. The nozzle for the suction tube was moved eccentrically away from the point of traction, thus allowing stronger oblique traction, and a second 'posterior' cup was designed for use when the fetal head is malpositioned. Suction is applied to the posterior cup through a nozzle on the side of the cup allowing greater manoeuvreability and more satisfactory cup application.

Traction on both anterior and posterior BIRD cups is applied to the centre of the dome of the cup. Oblique traction thus tends to tilt the cup and this may lead to detachment. BIRD has therefore recently modified his cups further. The 'New Generation' cups have a traction cord which passes around the rim of the cup for $180^{\circ}$ and is free to slide within this rim. It is claimed that the modification 'enables the

\section{Curriculum vitae}

Dr. CARMODY graduated in Medicine from the University of Queensland Australia in 1977. He commenced his specialist Obstetrics training in Britain in 1981. He was appointed as a registrar at St. Mary's Hospital Portsmouth in 1982. During his time at St. $\mathrm{Ma}$ ry's, he was particularly interested in the assessment

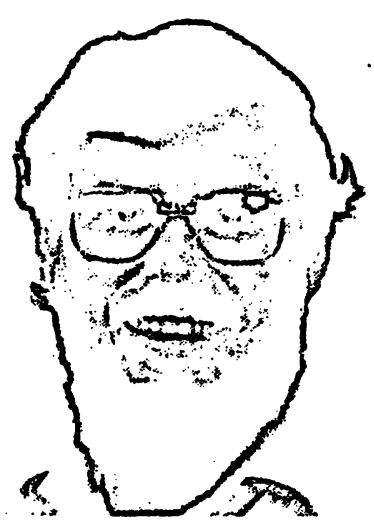
of different methods of operative vaginal delivery. He returned to Australia in 1983 and is currently Senior Registrar in Obstetrics and Gynecology at the Townsville General Hospital, North Queensland.

operator to pull obliquely (intentionally or unintentionally) without causing the cup to tilt' and thereby 'reduces failure rates, reduces the incidence of scalp trauma and increases operator confidence'.*

Such scalp trauma is a problem which is particular to vacuum extraction. In a recently conducted randomized comparison of vacuum extraction with forceps delivery [4] minor scalp

\footnotetext{
* AB Vacuum Extractor: Vacuum Extractor Manual, AB Vacuum Extractor, Goteborg 1982
} 
trauma was more common in the group allocated to vacuum extraction, especially when the head was malpositioned; neonatal jaundice was also more common in this group.

In that trial, BIRD's original design of cup was used. It was in the light of that trial's findings and the advantages claimed for the 'New Generation' cups that a further randomized controlled trial was mounted to compare the 'New Generation' cups with BIRD's original design of cup.

\section{Patients and methods}

The trial was conducted at St. Mary's Hospital, Portsmouth, between March and June 1983. Women eligible for entry were those with singleton pregnancies where the fetal presentation was cephalic, the gestational age was at least 37 completed weeks and where instrumental assistance was required for delivery. As soon as a decision had been taken to deliver by vacuum extraction a random allocation was made to either the original BIRD modified vacuum extractor cups or the 'New Generation' cups, by opening the top envelope in a box of serially-numbered, sealed, opaque envelopes. If the woman subsequently had a spontaneous vaginal delivery or was delivered by forceps or cesarean section she was not excluded from the primary analysis. This was therefore a comparison of "an intention" to deliver with one or other of the cup types. Secondary analyses compared the groups actually delivered with their allocated cup.

The maximum number of subjects (123) was recruited to the trial in the available time. A trial with 60 subjects in each group has a 50 per cent chance of showing a statistically significant difference between the two groups (2-tailed $\alpha=$ 0.05 ) if the real effect of using one cup is a reduction in the rate of (all) neonatal scalp trauma by a half from 30 per cent to 15 per cent. The Yates-corrected Chi-square and Student's t statistical tests were used in the analysis.

The comparability of the women allocated to the two groups, of the status of the operators,
Table I. Characteristics of the subjects in the two study groups.

\begin{tabular}{lcc}
\hline Descriptive variables & $\begin{array}{l}\text { New } \\
\text { Gener- } \\
\text { ation } \\
(\mathrm{n}=60)\end{array}$ & $\begin{array}{l}\text { Original } \\
\text { BuRD } \\
(\mathrm{n}=63)\end{array}$ \\
\hline Median age & 25 & 25 \\
Married (\%) & 82 & 81 \\
Nulliparous (\%) & 85 & 81 \\
Mean birthweight (kg) & 3.42 & 3.48 \\
Indications for vacuum extraction & & \\
fetal distress & 14 & 10 \\
delay - cervix fully dilated & 25 & 35 \\
delay - cervix not fully dilated & 1 & 2 \\
fetal distress + delay & 3 & 4 \\
stiorten second stage & 14 & 9 \\
other & 3 & 3 \\
Operator status & & \\
Consultant/Senior Registrar & 5 & 5 \\
Registrar & 28 & 33 \\
Obstetric trainee & 8 & 10 \\
General practice trainee & 19 & 15 \\
Experience level of operator & & \\
'A'> 20 rotations & 22 & 29 \\
'B' > 20 extractions & 10 & 9 \\
'C' < 20 extractions & 28 & 25 \\
\hline
\end{tabular}

and of the indications for vacuum extraction is shown in table I.

$50 \mathrm{~mm}$-sized anterior and posterior cups were used in both groups. Details of each procedure were recorded by the operator immediately after delivery. One of us (FC) examined each baby between 24 and 48 hours after delivery and photographed all trauma. Information about the infant's condition at birth and in the neonatal period was obtained from the casenotes. At the conclusion of the trial all operators were asked about their confidence in using the different cups and whether they had a preference for one or other type.

\section{Results}

The actual mode of delivery in the groups allocated to each type of extractor cup is shown in table II. In one case in each group the allocated cup was not available at the time of delivery. 
Equipment failure occured once in each group and these babies were delivered with forceps. The other three forceps deliveries were prompted by failure of the head to descend when traction was applied with the vacuum extractor. The indication for the single cesarean section was cephalopelvic disproportion.

The positions of cup application were similar in the two groups: the application was flexing and median in 74 per cent of cases in the 'New Generation' group and in 72 per cent in the 'Original BIRD' group.

Detachment of the cup occurred in nine cases allocated to the 'New Generation' cup as opposed to only four allocated to the 'Original BIRD' cup. There were no statistically significant differences in the number of pulls necessary for delivery (mean pulls in the 'New Generation' group 2.5 compared with 2.7 in the 'Original BIRD' group); nor in the time interval between entry to the trial and delivery (mean interval in 'New Generation' group 22.3 minutes compared with 20.9 minutes in the 'Original BIRD' group).

Table III describes the scalp trauma visible 48 hours after delivery; the overall rate and pattern were similar in the two groups. One baby in the 'New Generation' group whose mother was an epileptic being treated with phenytoin, sodium valproate and lorazepam, died because of extensive bleeding. At post-mortem examination extensive bleeding was visible beneath the scalp and neck and also in the ascending colon, kidneys, lungs and in a MECKEL's diverticulum. Coagulation studies revealed that the baby had clotting factor deficiencies, particularly in fibrinogen.

Other neonatal morbidity is summarized in table IV. There were no apparent differences in the condition of the two groups at birth. Clinically-apparent jaundice was more common in the 'New Generation' group (Relative risk 2.38 , Yates corrected chi square $=2.36,1 \mathrm{~d}$. f., $\mathrm{p}=0.13,95$ per cent confidence limits of relative risk $0.79-7.20$ ) and this difference was
Table II. Actual method of delivery.

\begin{tabular}{lll}
\hline Method of delivery & $\begin{array}{l}\text { New } \\
\text { Gener- } \\
\text { ation } \\
(\mathrm{n}=60)\end{array}$ & $\begin{array}{l}\text { Original } \\
\text { BiRD } \\
(\mathrm{n}=63)\end{array}$ \\
\hline New Generation cup & 51 & 1 \\
Original BIRD cup & 1 & 56 \\
Forceps & 2 & 3 \\
Cesarean section & 1 & 0 \\
Spontaneous vaginal delivery & 5 & 3 \\
\hline
\end{tabular}

Table III. Neonatal trauma sustained in the two study groups.

\begin{tabular}{lll}
\hline Neonatal trauma & $\begin{array}{l}\text { New } \\
\text { Gener- } \\
\text { ation } \\
(\mathrm{n}=60)\end{array}$ & $\begin{array}{l}\text { Original } \\
\text { BIRD } \\
(\mathrm{n}=63)\end{array}$ \\
\hline Bruising & 4 & 6 \\
Abrasion & 4 & 0 \\
Cephalhematoma & 2 & 2 \\
Subcutaneous hematoma & 7 & 11 \\
\hline
\end{tabular}

Table IV. Other neonatal morbidity.

\begin{tabular}{lll}
\hline Neonatal morbidity & $\begin{array}{l}\text { New } \\
\text { Gener- } \\
\text { ation } \\
(\mathrm{n}=60)\end{array}$ & $\begin{array}{l}\text { Original } \\
\text { BirD } \\
(\mathrm{n}=63)\end{array}$ \\
\hline Apgar score $<7$ at one minute & 10 & 8 \\
Apgar score $<7$ at five minutes & 2 & 0 \\
Endotracheal intubation & 4 & 7 \\
Admission to Special Care Nursery & 3 & 4 \\
Jaundice & 25 & 17 \\
\hline
\end{tabular}

reflected in more babies in the 'New Generation' group having bilirubin estimations over $200 \mu$ moles/litre (12 versus 5) and more receiving treatment with phototherapy (14 versus 7 ).

Secondary analyses based on deliveries with the allocated instrument produced very similar results.

Operators were equally divided in their preference of cup. 


\section{Discussion}

Many new techniques are introduced into clinical practice without prior evaluation and this often makes subsequent evaluation difficult or impossible. In an attempt to evaluate the claims made on behalf of the 'New Generation' vacuum extraction cup the new cup was first used at St. Mary's Hospital, Portsmouth, in the context of this randomized controlled trial.

The study provides little evidence to suggest that cup detachment and scalp trauma are reduced by the new design. Furthermore, neonatal jaundice was more common in babies allocated to the 'New Generation' cup. The strength of this study is that these estimates are unbiased. However, because of its size, this trial gives only a relatively imprecise estimate of the effects of the new cup in these respects; the true risk of neonatal jaundice associated with the 'New Generation' cup (95 per cent confidence limits) may be anything between a 21 per cent decrease and a 720 per cent increase. Ideally, further randomized controlled trials should be mounted to improve the precision of these estimates.

The operators were more familiar with the original BIRD cups and this may have affected their performance and opinions of the 'New Generation' cups. Their preference was equally divided between the two types of cup. Some thought that the new traction cord would make traction easier, others commented that it tended to get lost in the vagina or under the cup. Those who preferred the original BIRD cups thought that the chain traction mechanism was preferable because the traction handle could be moved closer to the cup as the fetal head descended.

The relative advantages and disadvantages of the two cups therefore appear to be small. Application of the cup in a flexing median position was equally successfully accomplished in the two groups and in this respect both these types of cup are likely to be preferable to the original MALMSTRÖM vacuum extractor cup, particularly if the fetal head is malpositioned.

\section{Summary}

A new design of vacuum extractor cup - 'the New Generation cup' - has recently been introduced into clinical practice. Its major modification is a traction cord which passes around the rim of the cup for $180^{\circ}$ and is free to slide within the rim. Claims that this design 'enables the operator to pull obliquely without causing the cup to tilt' and thereby 'reduces failure rates, reduces the incidence of scalp trauma and increases operator confidence' have been evaluated in a randomized controlled trial.

123 women with singleton pregnancies of 37 completed weeks or more, with a cephalic presentation and for whom a decision to deliver by vacuum extraction had been taken, were randomly allocated to the 'New Generation' cup or BIRD's original vacuum extractor cup; $50 \mathrm{~mm}$ anterior and posterior cups were used in both groups as appropriate.

The two groups were comparable at entry and delivered by obstetricians of similar status (table I). The two types of cup were similar in respect of number of failures to deliver with the vacuum extractor (table II), correct positioning of the cup, number of pulls required for delivery and time taken to expedite delivery. Cup detachments occurred in nine cases allocated to the "New Generation' cup compared with four allocated to the original BIRD cup.

The babies in the two groups were in similar condition at birth (table IV) and sustained similar amounts of scalp trauma (table III). Neonatal jaundice, both clinical (table IV) and biochemical, was more common in babies delivered with the 'New Generation cup' and this was reflected in greater use of phototherapy in this group. Operators were equally divided in their preference of cup.

This study provides little evidence that the use of the 'New Generation' cup is associated with a reduction in cup detachment and scalp trauma and an increase in operator confidence. These estimates, although unbiased, are, however, imprecise because of the size of the trial and ideally further randomized controlled comparisons are required to reduce imprecision. Nevertheless, on the basis of this study, the relative advantages and disadvantages of the two types of vacuum extractor cup appear to be small.

Keywords: Infant newborn, jaundice, random allocation, vacuum extraction. 


\section{Zusammenfassung}

Vakuumextraktion - der „New Generation cup“ und der „Original BIRD cup“ in einer randomisierten Kontrollstudie

Kürzlich wurde ein neuer Typ einer Saugglocke, der "New Generation cup", in die klinische Praxis eingeführt. Die Hauptmodifikation besteht in einer Zugschnur, die in einer Rinne am Rand der Glocke bis zu einem Winkel von $180^{\circ}$ frei gleiten kann. Der Anspruch, $\mathrm{da} ß$ dieses Modell es dem Operateur erlaubt, schräg zu ziehen, ohne daß sich die Glocke verkantet, ferner da $B$ die Erfolgsrate und die Sicherheit des Operateurs erhöht sowie Scalptraumen reduziert werden, wurde in einer randomisierten Kontrollstudie überprüft.

Das Kollektiv bestand aus 123 Frauen mit Einlingsschwangerschaften über der 37 . Woche und Feten in Schädellage. Nach der Indikation zur Vakuumextraktion wurde nach dem Zufallsprinzip entweder der „New Generation cup" oder die normale Saugglocke eingesetzt. In beiden Gruppen waren Glocken mit einem vorderen und hinteren Teil von je $50 \mathrm{~mm}$ passend.

Die beiden Gruppen hatten vergleichbare Ausgangsbefunde und wurden von Geburtshelfern mit gleicher Qualifikation entbunden (Tabelle I). Es fand sich kein Unter- schied in Bezug auf die Erfolgsrate (Tabelle II), korrektes Anlegen der Glocke, Anzahl der Züge und Dauer der Ausführung der VE. Bei Verwendung des „New Generation cup" kam es in 9 Fällen zum Abrutschen der Glokke, bei Verwendung des „BIRD cup“ in 4 Fällen.

Der klinische Zustand der Neugeborenen sowie die Häufigkeit von Scalptraumen war in beiden Gruppen vergleichbar (Tabellen III, IV). Hyperbilirubinämien (Tabelle IV) traten in der Gruppe mit dem „New Generation cup" häufiger auf, was sich in der Anzahl der notwendigen Phototherapien widerspiegelt.

Die Hälfte der Operateure bevorzugte den „New Generation cup“, die andere Hälfte den „BIRD cup“.

Die vorliegende Studie liefert keinen Anhalt dafür, daß beim Einsatz des "New Generation cup" die Glocke seltener abrutscht, Scalptraumen weniger häufig sind und die Sicherheit des Operateurs erhöht ist. Diese Einschätzung erfolgt ohne jedes Vorurteil. Sie ist jedoch auf Grund der geringen Fallzahl recht oberflächlich; d. h. es sind weitere randomisierte Kontrollversuche erforderlich. Jedoch scheinen sich die Vor- und Nachteile der beiden Saugglocken nur geringfügig zu unterscheiden.

Schlüsselwörter: Ikterus, Neugeborenes, Vakuumextraktion, Zufallsverteilung.

\section{Résumé}

Extraction par ventouse: comparaison randomisée et controlée entre la nouvelle génération de ventouse et la ventouse BIRD d'origine

Un nouveau modèle de ventouse - «La nouvelle génération de ventouse» - a récemment été introduite en pratique clinique. Sa modification principale est un cable de traction qui entoure la monture de la ventouse sur $180^{\circ}$ et qui peut coulisser à l'intérieur de la monture. On a évalué dans un essai randomisé et contrôlé l'affirmation que ce modèle permet à l'opérateur de tirer selon un axe oblique sans provoquer l'inclinaison de la cupule et ainsi de diminuer le taux d'échec, de réduire l'incidence des traumatismes du scalp et d'augmenter la confiance de l'opérateur. On a attribué par randomisation soit la nouvelle génération de ventouse soit la ventouse BIRD d'origine à 123 femmes, présentant une grossesse unique de 37 semaines révolues ou plus avec un fœtus en présentation céphalique et chez lesquelles une décision d'extraction par ventouse avait été prise; on a utilisé pour chaque groupe comme cela était approprié une cupule antérieure ou postérieure de $50 \mathrm{~mm}$.

Les deux groupes étaient comparables à l'entrée et les obstétriciens de statut similaire (tableau I). Les deux types de cupules étaient similaires en ce qui concerne le nombre d'échecs d'extraction par ventouse (tableau II), la mise en place correcte de la cupule, le nombre de tractions nécessaires pour l'accouchement, et la durée pour réaliser l'accouchement. Les cupules se sont détachées dans 9 cas pour la nouvelle génération de ventouse et dans 4 cas pour la ventouse BIRD d'origine.

Dans les deux groupes les nouveaux-nés étaient dans les mêmes conditions à la naissance (tableau IV) et avaient subi des traumatismes du scalp similaires (tableau III). Les enfants nés après utilisation de la nouvelle génération de ventouse ont eu plus fréquemment un ictère néonatal, à la fois clinique (tableau IV) et biologique, comme cela ressort de l'utilisation plus importante de la photothérapie dans ce groupe.

Les opérateurs étaient divisés de façon équivallente pour leur préférence des ventouses.

Cette étude ne fournit pas de preuves que l'utilisation de la «nouvelle génération» de ventouse s'accompagne d'une diminution du détachement des cupules, des traumatismes du scalp et d'une augmentation de la confiance des opérateurs. Ces estimations, bien que non biaisées, sont cependant imprécises en raison de la taille de l'échantillon et d'autres comparaisons ultérieures randomisées et contrôlées sont nécessaires pour diminuer l'imprécision. Toutefois, sur les bases de cette étude, les avantages et les inconvénients relatifs aux 2 types de ventouse apparaissent comme étant faibles.

Mots-clés: Ictère, nouveau-né, randomisation, ventouse. 


\section{References}

[1] BIRD, G. C.: The importance of flexion in vacuum extraction delivery. Br. J. Obstet. Gynaecol. 83 (1976) 194

[2] BIRD, G. C.: The use of the vacuum extractor. Clin. Obstet. Gynaecol. 9 (1982) 641

[3] Malmström, T.: The vacuum extractor, an obstetrical instrument. Acta Obstet. Gynecol. Scand. 36 [Suppl. 3] (1957) i 1

[4] Vacca, A., A. Grant, G. Wyatt, I. Chalmers: Portsmouth operative delivery trial: a comparison of vacuum extraction and forceps delivery. $\mathrm{Br}$. $\mathrm{J}$. Obstet. Gynaecol. 90 (1983) 1107

Received February 26, 1985. Accepted April 20, 1985.

Dr. Adrian Grant

National Perinatal Epidemiology Unit Radcliffe Infirmary

Oxford 2, U. K. 